\section{Hemidactylus mabouia (Tropical House Gecko). Distribution.}

Date of observation: 29 September 2011. Location: Big Ambergris Cay, Turks and Caicos Islands. Coordinates: 21.3069, -71.6313. Elevation: 7 m. Voucher: specimen (MPM 33997). This is the first report of this species from Big Ambergris Cay. This introduced species is established on the larger cays of the Caicos Bank and Grand Turk, but has previously never been recorded from the southeastern margin of the Caicos Bank (Reynolds, RG and ML Niemiller. 2010. Reptiles and Amphibians 17:117-121). This species was not present during surveys of this island 2007-2010 (RGR and Glenn P. Gerber) and has probably arrived with the importation of construction material from Providenciales. It is presently restricted to the immediate area near the operations campus, although it is expected to spread. Eight individuals were seen, including juveniles, at night on the walls of buildings. One voucher (a hatchling) was collected.

R. Graham Reynolds, University of Massachusetts Boston, Dept. of Biology, 100 Morrissey Blvd., Boston, Massachusetts, 02125, USA, robert.graham.reynolds@gmail.com.

Citation: Reynolds R. 2012. Hemidactylus mabouia (Tropical House Gecko). Distribution. Caribbean Herpetology 28:1. 